\title{
Additional records of black bear (Ursus americanus) in central-eastern México
}

\section{Registros adicionales de oso negro (Ursus americanus) en el centro-este de México}

Juan F. Charre-Medellín ${ }^{1,2 *}$, Francisco Botello ${ }^{3}$, Esmar O. Guzmán-Diaz ${ }^{4}$, Ma. Eugenia Mendiola-GonzalezZ ${ }^{5}$ Ulises Torres-Garcia ${ }^{6}$, Jorge I. Ángeles-EsCUdero ${ }^{7}$, And Octavio Rosas-Rosas ${ }^{8}$

'Escuela Nacional de Estudios Superiores Campus Morelia, Universidad Nacional Autónoma de México. Antigua carretera a Pátzcuaro 8701, C. P. 58190. Morelia, Michoacán, México. E-mail: jfcharre@yahoo.com.mx (JFCh-M).

${ }^{2}$ Centro de Investigaciones en Geografía Ambiental, Universidad Nacional Autónoma de México. Antigua carretera a Pátzcuaro 8701, C. P. 58190 . Morelia, Michoacán, México.

${ }^{3}$ Departamento de Zoología, Instituto de Biología, Universidad Nacional Autónoma de México. Circuito exterior S/N, C. P. 04510, Ciudad Universitaria, Ciudad de México, México. E-mail: francisco.botello@ib.unam.mx (FB).

${ }^{4}$ Facultad de Biología, Universidad Michoacana de San Nicolás de Hidalgo. Gral. Francisco J. Múgica S/N, C. P. 58030, Morelia, Michoacán, México. E-mail: ocelotlcuauhtli@gmail.com (EOG-D).

${ }_{5}^{5}$ Reserva de la Biosfera Sierra Gorda de Guanajuato, Comisión Nacional de Áreas Naturales Protegidas. Jiménez 222, Col. Centro, C. P. 37900, San Luis de la Paz, Guanajuato, México. E-mail: jilguero.maru@gmail.com (MEM-G).

${ }^{6}$ Reserva de la Biosfera Sierra Gorda, Comisión Nacional de Áreas Naturales Protegidas. Carretera 120 San Juan del Río-Xilitla esquina Andador Vicente Guerrero S/N, C. P. 76340, Jalpan de Serra, Querétaro, México. E-mail: ulises.torres@conanp.gob.mx (UT-G).

7Parque Nacional Los Mármoles, Comisión Nacional de Áreas Naturales Protegidas. C. P. 42000, Pachuca de Soto, Hidalgo, México. E-mail: jiangeles@conanp.gob.mx (JIA-E).

${ }^{8}$ Colegio de Postgraduados, Campus San Luis Potosí. Calle de Iturbide 73, C. P. 78600, Salinas de Hidalgo, San Luis Potosí, México. E-mail:octaviocrr@colpos.mx (OR-R).

*Corresponding author

The distribution range of the black bear (Ursus americanus) in México showed a significant reduction in the 20th century. However, growing evidence of its presence in areas outside the known range of distribution has emerged in recent years. This note documents a set of new records of black bear for the States of Guanajuato, Querétaro, and San Luis Potosí in central-eastern México. Black bears were spotted from monitoring that included camera traps, sightings, and indirect evidence (tracks and depredation events) between the years 2000 and 2019. We detected the presence of black bear through six records in the States of Guanajuato, Querétaro, and San Luis Potosí, in an area close to the southernmost distribution for this species in the American continent. Five of these observations occurred within protected natural areas. With these observations, the number of mammal species recorded in the State of Guanajuato increases to 95 and confirm the presence of black bear in the States of Querétaro and San Luis Potosí. The observations provide evidence supporting the hypothesis that black bear populations from northeastern México are moving toward central-eastern México through the Sierra Madre Oriental (SMO). The presence of black bear in central-eastern México points to the need for closer systematic monitoring of biodiversity in the SMO and protected areas of the region through monitoring and conservation programs.

Key words: Camera trap; distribution; protected natural area; Sierra Madre Oriental.

El oso negro (Ursus americanus) redujo significativamente su área de distribución en México en el siglo XX. En los últimos años, sin embargo, hay evidencia de su presencia en áreas fuera del rango de distribución propuesto. El objetivo es documentar un conjunto de registros nuevos de oso negro para los estados de Guanajuato, Querétaro y San Luis Potosí en el centro-este de México. Se detectaron osos negros como resultado de acciones de monitoreo que incluyeron cámaras trampa, avistamientos y observación indirecta (huellas y eventos de depredación), realizados entre los años 2000 y 2019. Detectamos la presencia de oso negro a través de seis registros en los estados de Guanajuato, Querétaro y San Luis Potosí, en un área cercana a la distribución más sureña para esta especie en el Continente Americano. Cinco de las observaciones ocurrieron dentro de áreas naturales protegidas. Las observaciones aumentan el número de especies de mamíferos registrados en el estado de Guanajuato a 95 y confirman la presencia del oso negro en los estados de Querétaro y San Luis Potosí. Las observaciones proveen evidencia que respalda la hipótesis de que las poblaciones de oso negro del noreste de México se mueven hacia el centro-este de México a través de la Sierra Madre Oriental (SMO). La presencia de oso negro en el centro-este de México señala la necesidad de intensificar el monitoreo sistemático de la biodiversidad en la SMO y en áreas protegidas de la región a través de programas de monitoreo y conservación.

Palabras clave: Área natural protegida; cámara trampa; distribución; Sierra Madre Oriental. 
The American black bear (Ursus americanus, Pallas, 1780) is the only ursid (Mammalia, Ursidae) and the largest carnivorous mammal distributed in México (Gavito-Pérez et al. 2012; Garshelis et al. 2016). The distribution of black bear in México is fragmented and restricted to small areas of the Sierra Madre Occidental (SMOcc) and Sierra Madre Oriental (SMO); the distribution and population size of the bear in much of the country are currently unknown (Gavito-Pérez et al. 2012; Garshelis et al. 2016). The black bear is considered an endangered species and a priority for conservation at the national level (SEMARNAT 2010; Gavito-Pérez et al. 2012). Currently, two subspecies of black bear are recognized in México, U. a. machetes and U. a. eremicus (Larivière 2001; Medellín et al. 2005; Ramírez-Pulido et al. 2014). The subspecies U. a. machetes is found in the States of Chihuahua, Durango, Sonora, Sinaloa, and Zacatecas in the SMOcc; the subspecies $U$. a. eremicus is located in the States of Coahuila, Nuevo Leon, Tamaulipas, and San Luis Potosí in the SMO (Gavito-Pérez et al. 2012; Juárez-Casillas and Varas 2013; Monroy-Vilchis et al. 2016).

During the 20th century, black bear populations in México declined significantly due to deforestation, hunting, and poisoning over livestock-predation issues. However, since 1980, these populations have recovered in some regions of northern México (Doan-Crider and Hewitt 2005; Delgadillo-Villalobos 2011; Delfín-Alfonso et al. 2012; Gavito-Pérez et al. 2012; Garshelis et al. 2016). Over the past 50 years, the density of black bear populations in regions of northwestern México has increased to reach the same levels reported for some areas of the United States (Doan-Crider 1996). This population growth is likely due to a reduction in the threats facing the species (hunting and poisoning), its high birth rate, and its natural dispersal from the available habitat in northern México (Hewitt and Doan-Crider 2007).

Recent genetic analyses have shown that black bear populations are displacing southward through the SMO in search of food, from northeast México to the center of the country (Aguilar-López et al. 2019; López-González et al. 2019). To date, the presence of bears had not been recorded in States such as Guanajuato. This paper reports new records of black bear in the southernmost portion of its range in the American continent and documents the presence of this species in four natural protected areas in central-eastern México.

The Sierra Madre Oriental (SMO) is one of the main mountain ranges of México, stretching from the border with the United States of America to central México, encompassing the states of Coahuila, Nuevo León, Tamaulipas, San Luis Potosí, Guanajuato, Querétaro, Hidalgo, and central Veracruz (Ruiz-Jiménez et al. 2004). The center of the SMO includes the Carso Huasteco physiographic subprovince that includes the region known as "Sierra Gorda", located east of Guanajuato, south of San Luis Potosí, north of Querétaro, and west of Hidalgo (Arreguín-Sánchez and Fernández-Nava 2004). It is characterized by its climatic and topographical variation associated with the presence of temperate, tropical, and cloud forest, and xeric shrublands, ranging from 300 to 3,100 m (Arreguín-Sánchez and Fernández-Nava 2004).

The biodiversity of the Sierra Gorda has warranted the creation of Natural Protected Areas (ANP, for its acronym in Spanish) aiming to conserve the species richness in the region and maintain the connectivity of vegetation types and ecological processes (Arreguín-Sánchez and Fernández-Nava 2004). There are four main ANP in the Sierra Gorda region: Sierra Gorda Biosphere Reserve (RBSG) in Querétaro, Sierra Gorda de Guanajuato Biosphere Reserve (RBSGG) in Guanajuato, Los Mármoles National Park in Hidalgo, and The Sierra de Álvarez Flora and Fauna Protection Area in San Luis Potosí; altogether, these areas protect an area of approximately 644,600 ha (Bezaury-Creel and Gutiérrez-Carbonell 2009).

Fieldwork has been conducted seeking to gain a more detailed insight into the biodiversity in States of centraleastern México, such as Guanajuato, Querétaro, and San Luis Potosí, particularly in the Sierra Gorda region, between 2000 and 2019. These have gathered records of black bears obtained through various research projects, which are described below.

In the State of Guanajuato, RBSGG staff, in collaboration with the civil association Conservación del Patrimonio Natural para el Bienestar Social (Natural Heritage Conservation for Social Welfare; COPANABIS), installed six camera traps (Black Flash, 20 MP, Cuddeback, Wl; Wildgame Innovations Infrared, 6.0 MP, Wildgame Innovations, LA) in the towns of El Carricillo and El Charco, municipality of Atarjea, between July and September 2018. All camera traps were placed along trails, ravines, and areas associated with water bodies, approximately one meter above ground level, and separated by a minimum distance of $500 \mathrm{~m}$ between them. In the case of San Luis Potosí and Querétaro, the records presented in this paper come from incidental encounters and not from a systematic sampling effort.

Additionally, to document and supplement the known distribution of black bear in the SMO - particularly in the area corresponding to the states of Guanajuato, San Luis Potosí, and Querétaro -, we searched the scientific literature for presence records (direct observations, photographs, skulls, tracks, excreta, and/or scientific collections). Combinations of key words such as "Ursus americanus", "oso negro", "black bear", "Guanajuato", "Querétaro", and "San Luis Potosi" were entered in search engines such as SciELO, Redalyc, and Google Scholar. In addition, records of the presence of black bear were gathered from Enciclovida, the National Commission for the Knowledge and Use of Biodiversity (CONABIO) (http://enciclovida.mx/), and the Global Biodiversity Information Facility (https://www.gbif.org/). Black bear records were projected on a map of the region as new and historical records: also marked were the distribution range of the species according to the International Union for the Conservation of Nature (IUCN), and the limits of the SMO and ANP (Figure 1). 


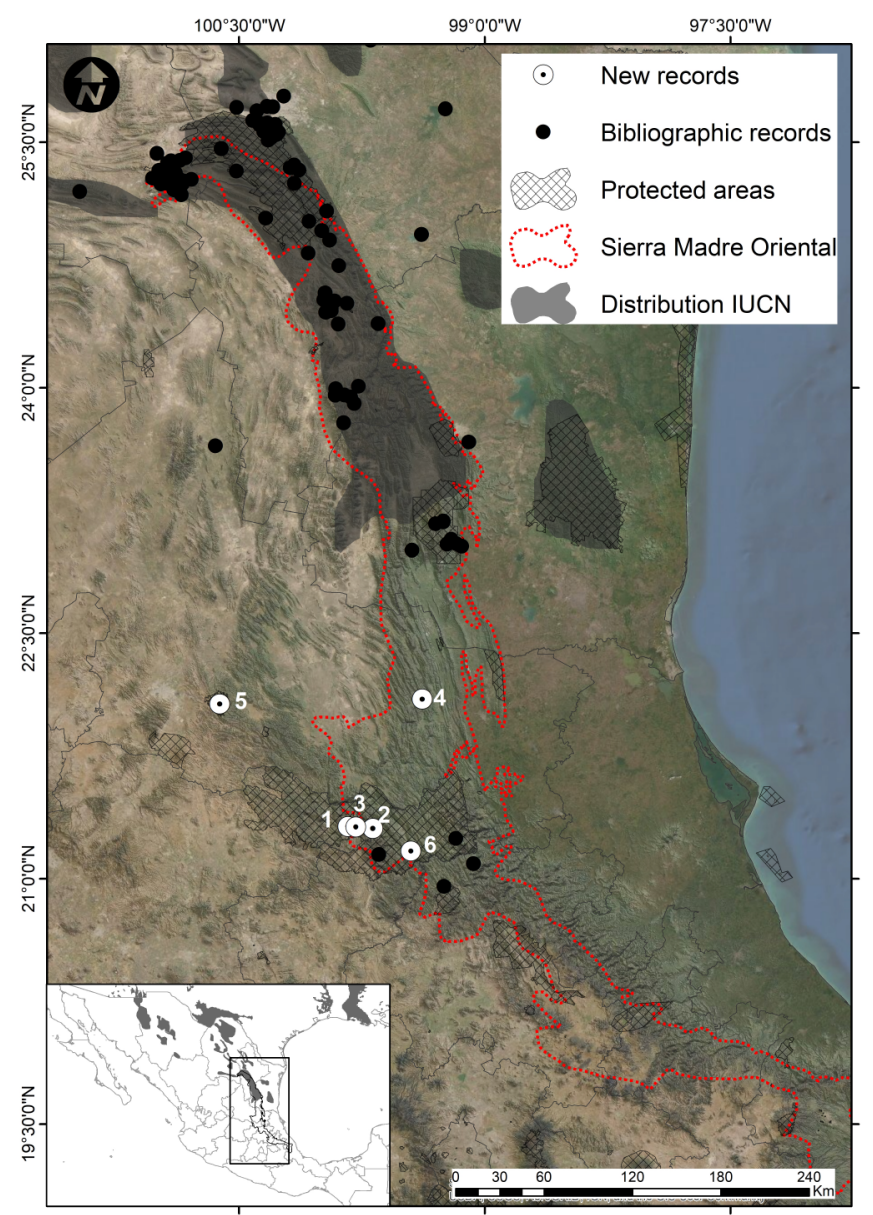

Figure 1. Geographic location of the new black bear records, Ursus americanus (white dots) in central-eastern México, and literature records in the Sierra Madre Oriental (black dots). 1 RBSGG, 2 RBSGG, 3 RBSGG, 4 Tamasopo, San Luis Potosí, 5 APFF Sierra de Álvarez, San Luis Potosí, 6 RBSG. RBSGG = Sierra Gorda de Guanajuato Biosphere Reserve; RBSG $=$ Sierra Gorda Biosphere Reserve; APFF = Flora and Fauna Protection Area.

This work resulted in six new direct (observations and photographs) and indirect (tracks, livestock predation events, and hunted specimens) records of black bear for central-eastern México between 2000 and 2019 (Table 1). These records are located in Guanajuato $(n=3)$, Querétaro $(n=1)$, and San Luis Potosí $(n=2$; Table 1$)$. Five records are located within an ANP (Table 1).

Three records of black bear were obtained within the RBSGG in the municipality of Atarjea, Guanajuato. The first corresponds to a sighting by members of the Biode- fensores group of the Ecochavos network in El Carricillo at 2,265 m on 11 July 2018. This observation was validated by RBSGG staff that assisted in the registration verification and obtained a plaster cast of the footprints (Figure $2 \mathrm{~A}$ ). According to the testimonies of people who watched the bear, it was an individual in good physical condition. Later, on 12 September 2018 and with a sampling effort of 420 camera trap days, we obtained two photographs of an American black bear at 10:37 hr in El Charco, at an altitude of $2,109 \mathrm{~m}$. The photographs suggest it was an adult individual (Figure 2B). Finally, on 6 October 2018, the reserve staff and COPANABIS found another black bear track in El Durazno at 2,379 m (Figure 2C). All reports of black bear for RBSGG refer to mixed oak-pine forests dominated by pinyon pine (Pinus cembroides).

For the State of Querétaro, on 30 May 2019 the RBSG staff verified and validated the observation of a black bear individual in El Carrizal, municipality of Jalpan de Serra, located at $893 \mathrm{~m}$ in a dry tropical forest (Figure 2D). This record is the first reported for this State in a tropical forest.

For San Luis Potosí, a black bear was hunted in 2000 by inhabitants of San Nicolás de Los Montes, municipality of Tamasopo. This record was validated from a photograph of the specimen, hunted at $860 \mathrm{~m}$ in the transition zone between oak forest and sub-deciduous tropical forest. Subsequently, in December 2009, the predation of a domestic pig by a black bear was reported in Valle de los Fantasmas, municipality of Zaragoza; the local inhabitants contacted the Wildlife Office of the State government to report the predation event because the bear was scared off with the help of domestic dogs. The report was verified and validated through testimonies and photographs of the predation taken by the locals. This record is located at 2,321 $\mathrm{m}$ in an oak forest within the Sierra de Álvarez Flora and Fauna Protection Area (Figure 1). These records represent the most recent and reliable evidence of the presence of black bear in San Luis Potosí.

The confirmed reports of black bear presence in the SMO that are geographically closest to the new records reported in this study are located at a distance of approximately $184 \pm 40 \mathrm{~km}$ north of El Cielo protected area, State of Tamaulipas (Vargas-Contreras and Hernández-Huerta 2001; Figure 1).

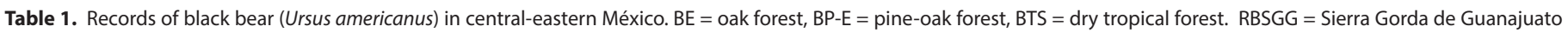
Biosphere Reserve; RBSG = Sierra Gorda Biosphere Reserve; APFF = Flora and Fauna Protection Area .

\begin{tabular}{|c|c|c|c|c|c|c|c|}
\hline Record & Locality & Longitude & Latitude & Elevation (m) & Vegetation & Year & Type of record \\
\hline 1 & El Carricillo, Atarjea, Guanajuato, RBSGG & -99.83574 & 21.31857 & 2,265 & BP-E & 2018 & Sighting and track \\
\hline 2 & El Charco, Atarjea, Guanajuato, RBSGG & -99.83574 & 21.31857 & 2,109 & BP-E & 2018 & Camera trap \\
\hline 3 & El Durazno, Atarjea, Guanajuato, RBSGG & -99.78617 & 21.31600 & 2,379 & BP-E & 2018 & Track \\
\hline 4 & $\begin{array}{l}\text { San Nicolás de los Montes, Tamasopo, } \\
\text { San Luis Potosí }\end{array}$ & -99.38139 & 22.09778 & 860 & $\mathrm{BE}$ & 2000 & Photograph of hunted specimen \\
\hline 5 & $\begin{array}{l}\text { Valle de los Fantasmas, Zaragoza, San } \\
\text { Luis Potosí, APFF Sierra de Álvarez }\end{array}$ & -100.61778 & 22.06806 & 2,321 & $\mathrm{BE}$ & 2009 & Domestic pig predation \\
\hline 6 & Carrizal, Jalpan de Serra, Querétaro, RBSG & -99.45077 & 21.16851 & 893 & BTS & 2019 & Sighting and photo \\
\hline
\end{tabular}




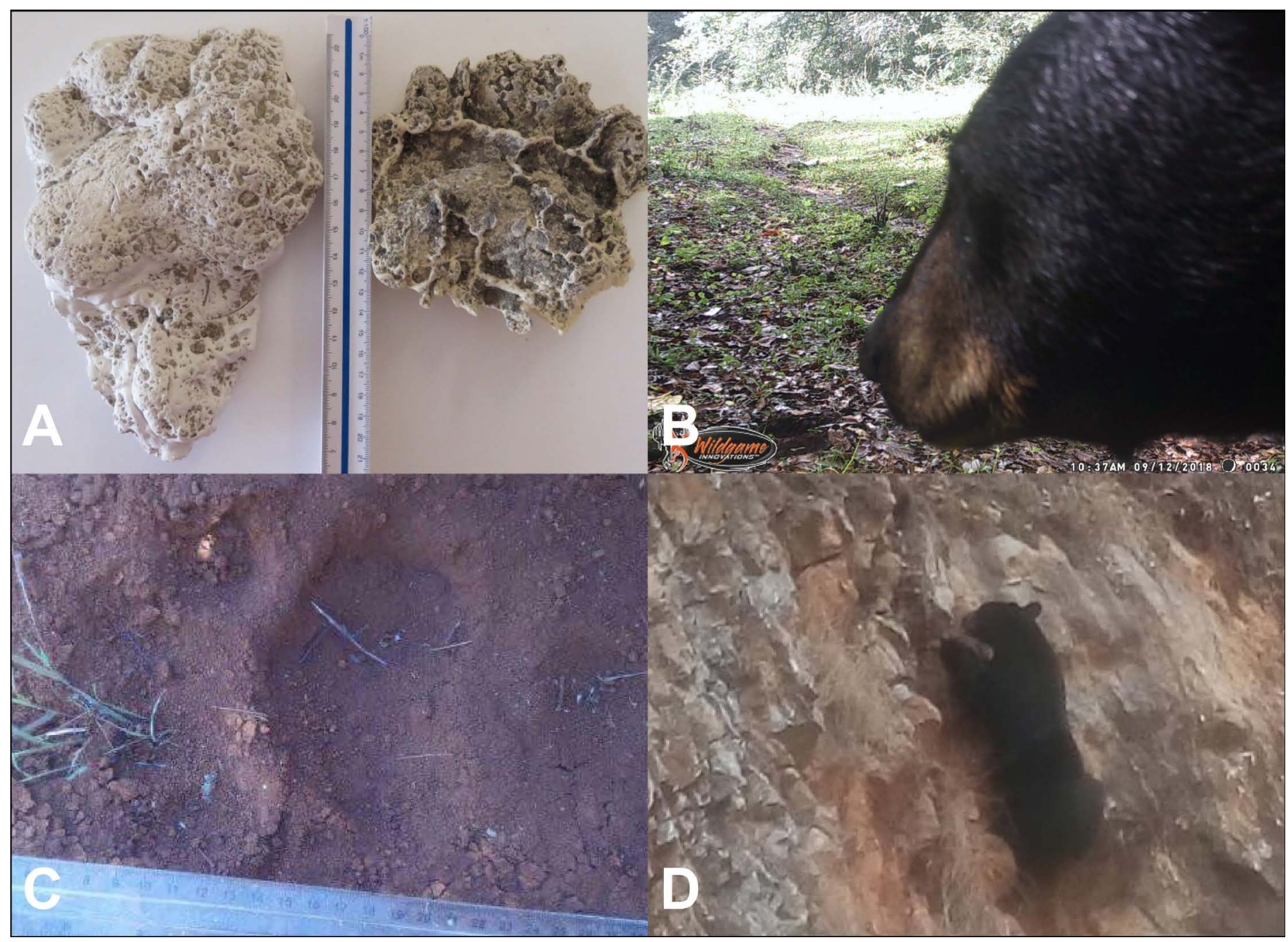

Figure 2. Evidence of the new records of black bear (Ursus americanus) in central-eastern México A) plaster casts of the footprint in the locality of El Carricillo, RBSGG, B) photograph taken at El Charco, RBSGG, C) footprint recorded in El Durazno, RBSGG, D) sighting in El Carrizal, RBSG. RBSGG = Sierra Gorda de Guanajuato Biosphere Reserve; RBSG = Sierra Gorda Biosphere Reserve.

The black bear records in central-eastern México presented here are located near the southernmost portion of the distribution of this species in the American continent (Lackey et al. 2013; Scheick and McCown 2014), and support the hypothesis raised by López-González et al. (2019) about the displacement of black bear from populations in northeastern México heading to central México through the SMO. These displacements possibly occur through temperate forests in the SMO mountain range, as most of the new and literature records are associated with this type of vegetation. Other authors have documented movements of black bear in search of food or territory in both México and the United States (Liley and Walker 2015; Camargo-Aguilera et al. 2017).

Natural stochastic events, such as forest fires, droughts, and hurricanes, could pose a threat to bears. However, they are likely to play a major role in the expansion of populations by promoting their movements from certain regions, which is essential for the long-term viability of the populations in the SMO. Movements occur more frequently in young individuals and adult males, which may be the case in the Sierra Gorda, as the pres- ence of females in the area has not been documented so far (Liley and Walker 2015; Servín et al. 2018).

The Sierra Gorda and its surroundings are currently protected by at least four ANP. However, in the area between the RBSGG in Guanajuato and the El Cielo ANP in Tamaulipas, where the black bear population closest to the localities reported here is located, there are no protected areas greater than $1,000 \mathrm{~km}^{2}-$ the size required to ensure connectivity between black bear populations in this SMO region (Hewitt and Doan-Crider 2007; Figure 1). Therefore, it is essential to identify the likely routes of movement and dispersion of black bear through the SMO, especially in the State of San Luis Potosí, where only historical or anecdotal reports of the black bear are available besides the records reported in this work (Juárez-Casillas and Varas 2013; Martínez de la Vega et al. 2016). Identifying potential corridors in regions where no ANP exist should be a priority for black bear conservation actions in México because the species needs between 200 and $1,000 \mathrm{~km}^{2}$ of habitat with food availability to survive (Hewitt and Doan-Crider 2007; Delgadillo-Villalobos 2011). 
New records in central-eastern México confirm the presence of black bear in the State of Guanajuato, increasing the number of mammals reported for the state to 95 species (Sánchez et al. 2016; Magaña-Cota et al. 2018), and confirm the current presence of the species in San Luis Potosí, adding to the anecdotal reports by Dalquest (1953). In addition, these reports add to those for the States of Querétaro and Hidalgo, where the presence of black bear was recently reported (Rojas-Martínez and Juarez-Casillas 2013; AguilarLópez et al. 2019; López-González et al. 2019).

The records reported in this work on the presence of black bear add to those for other carnivorous species in the region reported over the past 10 years, including ocelot (Leopardus pardalis), margay (Leopardus wiedii), and jaguarundi (Herpailurus yagouaroundi) in Guanajuato (Iglesias et al. 2008; Charre-Medellín et al. 2012). In the State of Hidalgo, the presence of tayra (Eira barbara) and jaguar (Panthera onca) was recently reported (Aguilar-López et al. 2015; Morales-García et al. 2014). These findings highlight the importance of the region as a priority for the conservation of large mammals.

The presence of black bear in central-eastern México points to the need for closer systematic monitoring of biodiversity in the SMO and ANP in this region through monitoring and conservation programs. These programs will facilitate the establishment of the species in the mid and long term, especially in areas where favorable habitat conditions are maintained, such as temperate forests.

\section{Acknowledgements}

We thank R. Ruiz and the community at El Charco, Atarjea, Guanajuato, S. Briones in Jalpan de Serra, and I. Alvarado Márquez in Los Mármoles National Park, for their support and assistance to carry out the field work. Thanks to V. León-Guerrero, A. Gil-Chavez, and A. González-Montes, the post-graduate students and the Ecochavos - Biodefensores group, and the SABES high-school students in the Carricillo for their assistance in field work. The Direction of the Sierra Gorda Biosphere Reserve of Guanajuato, through the Comisión Nacional de Áreas Naturales Protegidas (National Commission of Natural Protected Areas; CONANP) thanks the ThinkBlue Volkswagen, GIZ, and ECOYDES A. C. (PROCODES / 6760/2017) for their support in field work and data gathering. J. F. Charre-Medellín thanks DGAPA-UNAM and CIGA-UNAM for the postdoctoral fellowship. M. E. SánchezSalazar translated the manuscript into English.

\section{Literature cited}

Aguilar-López, M., J. Ramos-Frías, A. E. Rojas-Martínez, and C. Cornejo-Latorre. 2015. First Record of Jaguar (Panthera onca) from the State of Hidalgo, México. Western North American Naturalist 75:520-525.

Aguilar-López, M., L. Monter-Vargas, C. Cornejo-Latorre, and A. Hernández-Saintmartin. 2019. First Photo Evidence of the American Black Bear (Ursus americanus) in the Southwestern Limit of Its Distribution. Western North American Naturalist 79:124-129.
Arreguín-Sánchez, M., and R. Fernández-Nava. 2004. Flora: Flora de la Sierra Gorda, Querétaro. Pp. 193-214 in Biodiversidad de La Sierra Madre Oriental (Luna, I., J. Morrone, and D. Espinosa, eds.). Comisión Nacional para el Conocimiento y Uso de la Biodiversidad, Universidad Nacional Autónoma de México, México.

Bezaury-Creel, J., And D. Gutiérrez-Carbonell. 2009. Áreas naturales protegidas y desarrollo social en México. Pp. 385-431 in Capital Natural de México, Vol. II: Estado de Conservación y Tendencias de Cambio (CONABIO, ed.). Comisión Nacional para el Conocimiento y Uso de la Biodiversidad, México.

Camargo-Aguilera, M. G., N. E. Lara-Díaz, H. Coronel-Arellano, AND C. A. López-GonzÁlez. 2017. One black bear (Ursus americanus) connects the great sierras: Genetic evidence. Therya 8:277-281.

Charre-Medellín, J. F., V. Sánchez-Cordero, G. Magaña-Cota, M. Álvarez-Jara, And F. Botello. 2012. Jaguarundi (Puma yagouaroundi) in Guanajuato, Mexico. The Southwestern Naturalist 57:117-118.

Dalquest, W. W. 1953. Mammals of the Mexican state of San Luis Potosi. Louisiana State University Studies on Biology Science Series 1:1-229.

Delfín-Alfonso, C. A., C. López-González, and M. Equihua. 2012. Potential distribution of American black bears in northwest Mexico and implications for their conservation. Ursus 23:65-77.

Delgadillo-Villalobos, J. 2011. Técnicas de conservación y manejo de oso negro en México. Pp. 311-331 in Temas Sobre Conservación de Vertebrados Silvestres en México (Sánchez, O., P. Zamorano, F. Recagno, and H. Moya, eds.). Instituto Nacional de Ecología, SEMARNAT. México City, México.

DoAn-Crider, D. 1996. Population characteristics and home range dynamics of the black bear in northern Coahuila, Mexico. The Journal of Wildlife Management 60:398-407.

Doan-Crider, D., And D. G. Hewitt. 2005. El oso negro mexicano regresa de manera natural. Biodiversitas 63:1-5.

Garshelis, D. L., B. K. Scheick, D. L. Doan-Crider, J. J. Beecham, AND M. E. ObBard. 2016. Ursus americanus (errata version published in 2017). The IUCN Red List of Threatened Species 2016 e.T41687A114251609. https://dx.doi.org/10.2305/ IUCN.UK.2016-3.RLTS.T41687A45034604.en. Accessed on 29 October 2018.

Gavito-Pérez, F., T. Ruiz-Olvera, and J. Delgadillo-Villalobos. 2012. Programa de Acción para la Conservación de la Especie: Oso negro americano (Ursus americanus). Secretaría de Medio Ambiente y Recursos Naturales, Comisión Nacional de Áreas Naturales Protegidas, México. México City, México.

Hewitt, D., And D. Doan-Crider. 2007. Metapopulations, food and people: Bear management in northern Mexico. Pp. 165181 in Wildlife Science: Linking Ecological Theory and Management Applications (Fulbright, T., and D. G. Hewitt, eds.). CRC Press. Boca Raton, Florida, U. S. A.

Iglesias, J., V. Sánchez-Cordero, G. Magaña-Cota, R. Bolaños, M. Aranda, R. Hernández, And F. Botello. 2008. Noteworthy records of margay, Leopardus wiedii and ocelot, Leopardus pardalis in the state of Guanajuato, México. Mammalia 72:347-349.

JuÁRez-Casillas, L. A., AND C. VARAS. 2013. Revisión bibliográfica actualizada del oso negro en México. Therya 4:447-465.

Lackey, C. W., J. P. Beckmann, And J. Sedinger. 2013. Bear historical ranges revisited: Documenting the increase of a once- 
extirpated population in Nevada. The Journal of Wildlife Management 77:812-820.

LaRIVIĖRE, B. S. 2001. Ursus americanus. Mammalian Species 647:1-11.

LiLEY, S. G., AND R. WALKeR. 2015. Extreme movement by an American black bear in New Mexico and Colorado. Ursus 26:1-6.

López-González, C. A., M. Camargo-Aguilera, K. Saucedo, and N. LARA Díaz. 2019. A Wandering Black Bear (Ursus americanus, Pallas 1780) in the Sierra Gorda Biosphere Reserve, Queretaro. American Midland Naturalist 182:252-259.

Magaña-Cota, G., Y. Hortelano-Moncada, and M. Briones-Salas. 2018. First record of Myotis occultus (Vespertilionidae) in the State of Guanajuato, Mexico. Therya 9:247-250.

Martínez de la Vega, G., G. García-Marmolejo, J. Luévano-Esparza, R. García-Morales, C. E. Rangel-Rivera, and J. A. AscanioLÁRRAGA. 2016. La mastofauna en San Luis Potosí: conocimiento, diversidad y conservación. Pp. 367-404 in Riqueza y Conservación de los Mamíferos en México a Nivel Estatal (Briones-Salas, M., Y. Hortelano-Moncada, G. Magaña-Cota, G. Sánchez-Rojas, and J. E. Sosa-Escalante, eds.). Instituto de Biología, Universidad Nacional Autónoma de México, Asociación Mexicana de Mastozoología A. C. and Universidad de Guanajuato. México City, México.

Medellín, R., C. Manterola, M. Valdez, D. Hewitt, D. Doan-CridER, AND T. Fulbright. 2005. History, Ecology, and Conservation of the Pronghorn Antelope, Bighorn Sheep, and Black Bear in Mexico. Pp. 387-404 in Biodiversity, Ecosystems, and Conservation in Northern Mexico (Cartron, J., G. Ceballos, and R. Felger, eds.). Oxford University Press. New York, U. S. A.

Monroy-Vilchis, O., N. Castillo-Huitrón, M. Zarco-González, AND C. Rodríguez-Soto. 2016. Potential distribution of Ursus americanus in Mexico and its persistence: Implications for conservation. Journal for Nature Conservation 29:62-68.

Morales-García, J. J., A. Morales-García, and J. Chame-Cruz. 2014. Registros del tayra (Eira barbara Linneanus 1758) en el estado de Hidalgo, México. Revista Mexicana de Mastozoología Nueva Época 6:24-28.

Ramírez-Pulido, J., N. González-Ruiz, A. Gardner, and J. ArroyoCabrales. 2014. List of Recent Land Mammals of Mexico, 2014. Special Publications of the Museum of Texas Tech University 63.

Rojas-Martínez, A. E., And L. Juárez-Casillas. 2013. Primer registro de oso negro americano (Ursus americanus) para el estado de Hidalgo, México. Revista Mexicana de Biodiversidad 84:1018-1021.

Ruiz-Jiménez, C., O. Alcántara, And I. Luna. 2004. Medio físico: Límites. Pp. 7-24 in Biodiversidad de La Sierra Madre Oriental (Luna, I., J. Morrone, and D. Espinosa, eds.). Comisión Nacional para el Conocimiento y Uso de la Biodiversidad, Universidad Nacional Autónoma de México. México City, México.

Sánchez, O., J. Charre-Medellín, G. Téllez-Girón, O. Báez-Montes, And G. Magaña-Cota. 2016. Mamíferos silvestres de Guanajuato: actualización taxonómica y diagnóstico de conservación. Pp. 243-280 in Riqueza y Conservación de los Mamíferos en México a Nivel Estatal (Briones-Salas, M., Y. Hortelano-Moncada, G. Magaña-Cota, G. Sánchez-Rojas, and J. Sosa-Escalante, eds.). Instituto de Biología, Universidad Nacional Autónoma de México, Asociación Mexicana de Mastozoología A. C. and Universidad de Guanajuato. Guanajuato, México.
Scheick, B. K., AND W. McCown. 2014. Geographic distribution of American black bears in North America. Ursus 25:24-33.

Semarnat (Secretaría de Medio Ambiente y Recursos Naturales). 2010. Norma Oficial Mexicana NOM-059-SEMARNAT-2010, Protección ambiental- Especies nativas de México de flora y fauna silvestres-Categorías de riesgo y especificaciones para su inclusión, exclusión o cambio-Lista de especies en riesgo. Diario Oficial de la Federación 30 diciembre, 2010. México City, México.

Servín, J., D. Carreón-González, A. Huerta-García, F. CastroCampos, And L. González-Saravia. 2018. Record of american black bear (Ursus americanus) in Durango, Mexico. Therya 9:261-264.

Vargas-Contreras, J. A., And A. Hernández-Huerta. 2001. Distribución altitudinal de la mastofauna en la Reserva de la Biosfera" El Cielo", Tamaulipas, México. Acta Zoológica Mexicana 82:83-109.

Associated editor: Cristian Kraker-Castañeda

Submitted: June 12, 2020; Reviewed: January 19, 2021.

Accepted: January 26, 2021; Published on line: February 5, 2021. 